\title{
PENYULUHAN HUKUM TENTANG PENDAFTARAN TANAH MENJAMIN KEPASTIAN HUKUM DI DESA IRINGMULYO KOTA METRO
}

\author{
Upik Hamidah, Nurmayani, Ati Yuniati, FX. Sumarja \\ Bagian Hukum Administrasi Negara Fakultas Hukum Universitas Lampung, Bandar Lampung \\ Jl. Prof. Sumantri Brojonegoro No.1 Bandar Lampung 35145
}

\begin{abstract}
ABSTRAK
Kegiatan penyuluhan hukum tentang Pendaftaran Tanah Menjamin Kepastian Hukum di desa Desa Iringmulyo Kota Metro ini bertujuan untuk memberikan pemahaman dan pengetahuan kepada masyarakat Desa Iringmulyo tentang Pendaftaran tanah sesuai dengan Peraturan Perundangundangan, hal ini dilakukan karena meskipun pada tahun 2019 telah diadakan program PTSL di Kota Metro, tetapi beberapa masyarakat di Desa Iringmulyo belum melakukan pendaftaran tanah. sehingga tim mengusul memiliki target setelah dilakukannya penyuluhan hukum ini, mengharapkan pengetahuan masyarakat tentang pendaftaran tanah sebagai jaminan kepastian hukum hak atas tanah dan meningkatkan kesadaran masyarakat dalam hal pentingnya pendaftaran tanah. Metode yang akan digunakan dalam penyuluhan ini adalah metode ceramah, diskusi dan demonstran. Metode ceramah dengan memberikan materi tentang pendaftaran tanah oleh tim pengusul, kemudian tim pengusul dan masyarakat melakukan diskusi terkait materi yang telah disampaikan serta memberikan gambaran mengenai tata cara melakukan pendaftaran tanah. Sasaran dalam kegiatan ini adalah masyarakat dan aparat desa tempat lokasi penyuluhan hukum yaitu Desa Iringmulyo Kota Metro dan tim pengusul berharap bahwa hasil dari kegiatan penyuluhan hukum tentang pendaftaran tanah sesuai dengan tujuan dari diadakan penyuluhannya.
\end{abstract}

Kata Kunci: Pendaftaran tanah, Jaminan Kepastian Hukum, Desa Iringmulyo

\section{Pendahuluan}

UUPA merupakan peraturan dasar yang mengatur penguasaan, pemilikan, peruntukan, penggunaan, dan pengendalian pemanfaatan tanah yang bertujuan terselenggaranya pengelolaan dan pemanfaatan tanah untuk sebesar-besar kemakmuran rakyat. Salah satu aspek yang dibutuhkan untuk tujuan tersebut adalah mengenai kepastian hak atas tanah yang menjadi dasar utama dalam rangka kepastian hukum kepemilikan tanah. Untuk menjamin kepastian hukum tersebut, UUPA menegaskan dalam Pasal 19 Ayat (1) yang berbunyi: "Untuk menjamin kepastian hukum olehpemerintah diadakannya Pendaftaran Tanah di seluruh wilayah Indonesia menurut ketentuan yang diatur dengan Peraturan Pemerintah".

Berpatokan pada perkembangan yang begitu pesat dan banyaknya persoalan pendaftaran tanah yang muncul ke permukaan dan tidak mampu diselesaikan oleh Peraturan Pemerintah Nomor 10 Tahun 1961, maka setelah berlaku selama kurang lebih 38 tahun, untuk selanjutnya pemerintah telah mengeluarkan Peraturan Pemerintah Nomor 24 Tahun 1997 tentang Pendaftaran Tanah. Pendaftaran tanah yang diatur dalam Peraturan Pemerintah No. 24 Tahun 1997 tentang pendaftaran tanah dilaksanakan berdasarkan azas sederhana, aman, terjangkau, mutakhir dan terbuka.

Menurut Pasal 3 Peraturan Pemerintah Nomor 24 Tahun 1997, ditegaskan bahwa tujuan pendaftaran tanah adalah Untuk memberikan kepastian hukum dan perlindungan hukum kepada pemegang hak atas tanah; untuk menyediakan informasi kepada pihak-pihak yang berkepentingan termasuk pemerintah, agar dengan mudah memperoleh data tentang sebidang tanah jika diperlukan.

Pemerintah mempunyai peran penting dalam hal menyadarkan masyarakat untuk melakukan pendaftaran tanah. Oleh karena itu pemerintah saat ini sedang giatnya melakukan Program Pendaftaran Tanah Sistematis Lengkap (PTSL) ini menyasar seluruh lapisan masyarakat di kawasan yang rentan sengketa tanah karena mayoritas masyarakatnya belum memiliki sertifikat. Jika masyarakat tersebut belum mendaftarkan tanahnya di Badan Pertanahan Nasional (BPN) maka pemerintah secara 
keseluruhan akan menyisir wilayah tersebut dengan program PTSL. PTSL merupakan berwujudan dari Program land reform atau reformasi agraria sebagaimana termasuk dalam program Nawacita. Akan tetapi, dalam perjalannya dibeberapa daerah meskipun telah menjalankan Program PTSL masih saja terdapat sengketa tanah ataupun target pendaftaran tanah tidak tercapai, hal ini dikarenakan kurangnya animo masyarakat dalam pentingnya melakukan pendaftaran tanah.

Berdasarkan uraian diatas, semakin besarnya kebutuhannya masyarakat akan tanah, meskipun pemerintah telah melakukan berbagai program apabila tidak diimbangi dengan pengetahuan pentingnya pendaftaran tanah dan peran serta masnyarakat dalam melakukan kegiatan pendaftaran tanah, akan menimbulkan tidak efektifan dalam pelaksanaan program pendaftan tanah, sehingga diperlukanpenyuluhan guna meningkatan SDM masyarakat tersebut.

Kota Metro merupakan salah satu kabupaten di Provinsi Lampung, yang giat menggalakkan program PTSL bagi masyarakatnya sehinggar target pendaftan tanah di kota metro menargetkan bahwa akhir 2020 tanah di kota metro memiliki sertifikat tanah hak milik. Kecamatan Metro Timur Kota Metro merupakah salah satu target program PTSL, Kepala Seksi (Seksi) Hubungan Hukum Pertanahan (HHP) BPN Kota Metro, Kustulani menyampaikan, target tersebut dari tahun 2019 sekitar 12.890 bidang tanah telah tersertifikat, dan pada tahun 2020 ini BPN Kota Metro amenargetkan targer 2000 bidang. Meskipun pada tahun 2019 telah di diadakan program PTSL di Kecamatan Metro Timur, namun pada kenyataannya sebanyak 510 bidang tanah belum tersertifikat, desa Iringmulyo merupakan salah satu desa di kecamatan metro timur kota Metro yang belum menjalankan program PTSL dengan baik karena terdapat beberapa warga yang tanahnya belum tersertifkat, hal ini terjadi dikarena beberapa masyarakat di desa iringmulyo belum mengetahui pentingnya pendaftaran tanah guna menjamin kepastian hukum. Dengan demikian diperlukan suatu kegiatan guna meningkatkan pengetahuan masyarakat Desa Iringmulya yang diharapkan mampu meningkatkan kesadaran masyarakat mengenai pentingnya kegiatan pendaftaran tanah.

\section{Bahan dan Metode}

Berdasarkan uraian analisi situasi diatas, maka yang menjadi permasalah dalam kegiatan pengabdian kepada masyarakat di Desa Iringmulyo Kota Metro adalah adalah sebagai berikut:

1. Bagaimanakah meningkatan pengetahuan masyarakat di Desa Iringmulyo Kota Metro tentang Pendaftaran Tanah Menjamin Kepastian Hukum?

2. Bagaimanakah meningkatkan kesadaran masyarakat di Desa Iringmulyo Kota Metro tentang pentingnya pendaftaran tanah?

Tujuan dari kegiatan pengabdian kepada masyarakat di Desa Iringmulyo Kota Metro adalah sebagai berikut:

1. Agar meningkatan pengetahuan masyarakat di Desa Iringmulyo Kota Metro tentang Pendaftaran Tanah Menjamin Kepastian Hukum 2. Untuk meningkatkan kesadaran masyarakat di Desa Iringmulyo Kota Metro tentang pentingnya pendaftaran tanah

Manfaat yang diharapkah setelah selesainya kegiatan pengabdian kepada masyarakat di Desa Iringmulyo Kota Metro adalah sebagai berikut:

1. Meningkatnya pengetahuan masyarakat di Desa Iringmulyo Kota Metro tentang Pendaftaran Tanah Menjamin Kepastian Hukum, sehingga meningkatnya minat masyarakat untuk melakukan pendaftaran tanah

2. Terciptanya kesadaran kesadaran masyarakat di Desa Iringmulyo Kota Metro tentang pentingnya pendaftaran tanah, sehingga masyarakat dapat mengetahui tata cara pendaftaran tanah.

Dari segi istilah, ditemukan istilah pendaftaran tanah dalam bahasa latin disebut "Capitastrum", di Jerman dan Italia disebut "Catastro", di Perancis disebut "kadastrale" atau "kadaster". Maksud dari Capitastrum atau kadaster dari segi bahasa adalah suatu register atau capita atau unit yang diperbuat untuk pajak tanah Romawi, yang berarti suatu istilah teknis untuk record (rekaman) yang menunjuk kepada luas, nilai dan kepemilikan atau pemegang hak atas suatu bidang tanah, sedang kadaster yang modern bisa terjadi atas peta yang ukuran besar dan daftar-daftar yang berkaitan. Istilah teknis bahasa Belanda, kadaster adalah suatu rekaman yang menunjukkan letak, luas, nilai dan kepemilikan terhadap suatu bidang tanah. 
Menurut Maria Sumardjono, Kadaster merupakan suatu daftar yang melukiskan semua persil tanah yang ada dalam suatu daerah berdasarkan pemetaan dan pengukuran yang cermat. Sedangkan Subekti dan Tjitro Sudibyo, menyatakan Kadaster merupakan suatu lembaga yang ditugaskan menyelenggarakan pendaftaran tanah dengan maksud untuk menetapkan identifikasi tiap-tiap potongan tanah (persil) dan mencatat tiap-tiap pergantian pemilik (pemindahan hak milik) begitu pula hak-hak kebendaan yang membebani tanah-tanah itu, seperti hipotek, gadai tanah dan lain-lain. Juga hak kebendaan lain atas tanah, hak guna bangunan, hak guna usaha dan lain-lain. Sedangkan Boedi Harsono, menyatakan bahwa pendaftaran tanah adalah suatu rangkaian kegiatan yang dilakukan oleh Negara/Pemerintah secara terus menerus dan teratur, berupa pengumpulan keterangan atau data tertentu mengenai tanah-tanah tertentu yang ada di wilayah-wilayah tertentu, pengelolaan, penyimpanan dan penyajian bagi kepentingan rakyat, dalam rangka memberikan jaminan kepastian hukum di bidang pertanahan, termasuk penerbitan tanda buktinya dan pemeliharaannya.

Sedangkan pengertian berdasarkan Pasal 1 angka satu Peraturan Pemerintah Nomor 24 Tahun 1997 sebagai penyempurna dari Peraturan Pemerintah No. 10 Tahun 1961 tentang Pendaftaran Tanah, menyatakan bahwa "Pendaftaran tanah adalah serangkaian kegiatan yang dilakukan oleh pemerintah secara terus menerus, berkesinambungan dan teratur, meliputi pengumpulan, pengolahan, pembukuan dan penyajian serta pemeliharaan data fisik dan data yuridis, dalam bentuk peta dan daftar, mengenai bidang-bidang tanah dan satuansatuan rumah susun, termasuk pemberian surat tanda bukti haknya bagi bidang-bidang tanah yang sudah ada haknya dan hak milik atas satuan rumah susun serta hak-hak tertentu yang membebaninya

Tujuan pendaftarran tanah yang bersifat hukum menginginkan kepastian mengenai siapa pemegang hak milik atau hak-hak lain atas sebidang tanah, ini di pandang dari segi hukum. Muhammad Yamin Lubis dan Abd. Rahim Lubis mengemukakan bahwa tujuan pendaftaran tanah yang dimaksud Peraturan Pemerintah Nomor 10 Tahun 1961 adalah demi kepastian hukum 'Rechtscadaster' dan tanahnya meliputi: tanah eks hukum adat, tanah konversi serta tanah yang lahir karena surat putusan Pemerintah. Hal ini sejalan dengan tujuan utama dari pendaftaran tanah di Indonesia mengacu pada Pasal 19 UUPA, tidak lain adalah dalam rangka memberikan jaminan kepastian hukum di bidang pertanahan.

Pemberian jaminan kepastian hukum terhadap hak-hak atas tanah bagi rakyat seluruhnya merupakan salah satu tujuan pokok UUPA yang sudah tidak bisa ditawar lagi, sehingga undang-undang menginstruksikan kepada Pemerintah untuk mengadakan pendaftaran tanah di seluruh wilayah Indonesia yang bersifat rechtskadaster artinya yang bertujuan menjamin kepastian hukum dan kepastian haknya.

Metode yang dipandang relevan untuk mencapai tujuan di atas adalah metode ceramah dan metode diskusi, yaitu metode yang digunakan untuk menyampaikan materi tentang Pendaftaran Tanah Menjamin Kepastian Hukum. Dalam metode ini dimungkinkan sekali diberikan suatu pemahaman dan pengetahuan tentang kepastian hukum dalam pendaftaran tanah

\section{Hasil dan Pembahasan}

Untuk mengetahui tingkat keberhasilan atau kegagalan penyuluhan ini, maka kepada khalayak sasaran kegiatan perlu dilakukan evaluasi kegiatan. Evaluasi dilakukan secara spesifik untuk mengetahui tingkat pengetahuan dan pemahamannya terhadap Pendaftaran Tanah Menjamin Kepastian Hukum Sesuai dengan peraturan perundang-undangan. Adapun langkah-langkah evaluasinya meliputi:

Evaluasi Awal

Pada saat akan dilaksanakan penyuluhan, terlebih dahulu dilakukan pretest, dialog dan perbincangan kepada peserta penyuluhan untuk lebih meyakinkan tim pengabdian masyarakat terhadap gambaran, kemampuan serta pengetahuan dasar kelompok sasaran mengenai materi penyuluhan pendaftaran tanah dalam menjamn kepastian hukum. Berdasarkan hasil dialog dan perbincangan sebagian besar kelompok sasaran belum mengetahui mengenai arti penting pendaftaran tanah guna menjamin kepastian hukum hak atas tanah

Masih banyak dari khalayak sasaran yang belum membaca dan mempunyai peraturan perundang-undangan yang berhubungan dengan pendaftaran tanah. Tidak heran apabila mereka tidak mengetahui tentang tujuan dan fungsi pendaftaran tanah, obyek pendaftaran tanah, kepastian hukum dalam pendaftaran tanah dan 
hal-hal yang berkenaan dengan pendaftaran tanah.

\section{Evaluasi Proses}

Evaluasi Proses dilakukan selama proses kegiatan penyuluhan hukum berlangsung, selama proses penyuluhan hukum semua peserta yang terlibat dalam penyuluhan memiliki keseriusan dan apresiasi yang sangat baik, para narasumber dengan sungguh-sungguh memberikan penyuluhan dan bimbingan dengan baik, demikian juga dengan peserta selalu mengikuti penyuluhan dengan tekun dan penuh minat, sehingga pelaksanaan penyuluhan berjalan dengan lancar, banyaknya peserta yang mengikuti penyuluhan kali ini adalah sebanyak 35 orang.

Hal ini dapat dilihat dari kehadiran peserta dan tim yang datang tepat waktu sesuai dengan waktu penyuluhan, mengikuti tata tertib penyuluhan yang disepakati bersama yaitu karena penyuluhan diadakan saat masa pendemi covid 19 maka penyuluhan diadakan dengan menggunakan protokol kesehatan sesuai dengan aturan dalam menghadapi covid 19, tidak ada peserta yang pulang atau tidak masuk dalam jam-jam yang telah ditentukan sebelum kegiatan penyuluhan selesai. Disamping itu, di setiap kesempatan banyak digunakan oleh peserta dengan tim pengabdian untuk berbincangbincang dan diskusi yang berhubungan dengan materi penyuluhan.

Evaluasi Akhir

Berdasarkan hasil evaluasi kegiatan terhadap pelasanaan penyuluhan, dapat dikemukakan bahwa terdapat peningkatan pengetahuan peserta penyuluhan tentang materi yang diberikan. Hal ini dapat diketahui dari evaluasi kegiatan yang dilakukan sebanyak dua kali; Pertama, pada awal kegiatan penyuluhan dalam bentuk tanya jawab dan melihat hasil pekerjaan atau tugas yang diberikan oleh panitia penyuluhan dengan cara memberikan soal pretest kepada peserta penyuluhan. Kedua, pada akhir kegiatan dilakukan post test kepada para peserta penyuluhan terhadap semua materi yang disampaikan, Hasil yang dapat dicapai para peserta ditunjukkan dengan melihat perkembangan hasil evaluasi akhir (En) dikurangi hasil evaluasi awal (Ea) atau $\mathrm{K}=(\mathrm{En})$ - (Ea). maka dapat disimpulkan pengetahuan peserta akan pendaftaran tanah dalam menjamin kepastian hukum meningkat

Kriterian Keberhasilan

Jika terjadi perubahan pengetahuan dan pemahaman hokum, yaitu dari tidak tahu menjadi tahu, dari tidak atau kurang paham tentang pendaftaran tanah dalam menjamin kepastian hukum menjadi paham, maka penyuluhan ini dikatakan berhasil. Tingkat perubahan kedua hal tersebut di atas dapat dilihat dari selisih antara hasil pra uji dan hasil pasca uji yang meliputi tingkat perubahan pengetahuan dan pemahaman. Jika (x1, x2) lama rendah, setelah dilakukan kegiatan berubah menjadi $\mathrm{P}$ $(1 \mathrm{x}, 2 \mathrm{x})$ baru meningkat atau lebih tinggi, maka tingkat pencapaian pengetahuan khalayak sasaran kegiatandapat dikatakan berhasil. Adapun hasil evaluasi yang telah dianalisis disajikan pada tabel satu. 
Tabel 1. Hasil Evaluasi Pretest dan Postest pada kegiatan pengabdian masyarakat tentang Penyuluhan Hukum tentang Pendaftaran Tanah Menjamin Kepastian Hukum di Desa Iringmulyo Kota Metro.

\begin{tabular}{|c|c|c|c|c|c|c|c|c|c|}
\hline \multirow{2}{*}{ No } & \multirow{2}{*}{ Nama } & \multirow{2}{*}{$\begin{array}{l}\sum_{\text {Maks. }} \mathrm{Sk} \\
\end{array}$} & \multicolumn{2}{|c|}{$\sum$ Sekor yang Diperole } & \multicolumn{2}{|c|}{$\%$ Ketercapaian } & \multicolumn{3}{|c|}{ Pemahaman } \\
\hline & & & Pretest & Postest & Pretest & Postest & Meningkd & Turun & Tetap \\
\hline 1 & Nursanti & 10 & 3 & 9 & $30 \%$ & $90 \%$ & $\sqrt{ }$ & & \\
\hline 2 & Johans & 10 & 2 & 7 & $0 \%$ & $70 \%$ & $\sqrt{ }$ & & \\
\hline 3 & Sabdo Suwito & 10 & 5 & 10 & $50 \%$ & $100 \%$ & $\sqrt{ }$ & & \\
\hline 4 & Ismanto & 10 & 2 & 9 & $20 \%$ & $90 \%$ & $\sqrt{ }$ & & \\
\hline 5 & Darto & 10 & 1 & 9 & $10 \%$ & $90 \%$ & $\sqrt{ }$ & & \\
\hline 6 & Ujang Ayoadi & 10 & 0 & 8 & $0 \%$ & $80 \%$ & $\sqrt{ }$ & & \\
\hline 7 & Elyanto & 10 & 7 & 7 & $70 \%$ & $70 \%$ & & & $\sqrt{ }$ \\
\hline 8 & Suprapto & 10 & 4 & 10 & $40 \%$ & $100 \%$ & $\sqrt{ }$ & & \\
\hline 9 & I Nyoman Darmandi & 10 & 3 & 6 & $30 \%$ & $60 \%$ & $\sqrt{ }$ & & \\
\hline 10 & Resmi Nurhayati & 10 & 3 & 8 & $30 \%$ & $80 \%$ & $\sqrt{ }$ & & \\
\hline 11 & Roji & 10 & 5 & 10 & $50 \%$ & $100 \%$ & $\sqrt{ }$ & & \\
\hline 12 & Dewi R.N & 10 & 1 & 10 & $10 \%$ & $100 \%$ & $\sqrt{ }$ & & \\
\hline 13 & Paini & 10 & 3 & 10 & $30 \%$ & $100 \%$ & $\sqrt{ }$ & & \\
\hline 14 & Nastutiliana & 10 & 2 & 80 & $20 \%$ & $80 \%$ & $\sqrt{ }$ & & \\
\hline 15 & Suwarto & 10 & 8 & 8 & $80 \%$ & $80 \%$ & & & $\sqrt{ }$ \\
\hline 16 & Haris & 10 & 7 & 7 & $70 \%$ & $70 \%$ & & & $\sqrt{ }$ \\
\hline 17 & Istiqomah & 10 & 5 & 10 & $50 \%$ & $100 \%$ & $\sqrt{ }$ & & \\
\hline 18 & Nisa Kusumawati & 10 & 3 & 8 & $30 \%$ & $80 \%$ & $\sqrt{ }$ & & \\
\hline 19 & Rori Koryani & 10 & 0 & 70 & $0 \%$ & $70 \%$ & $\sqrt{ }$ & & \\
\hline 20 & Yahya Wijaya Hamid & 10 & 3 & 8 & $30 \%$ & $80 \%$ & $\sqrt{ }$ & & \\
\hline 21 & Pitri Agustina & 10 & 0 & 8 & $0 \%$ & $80 \%$ & $\sqrt{ }$ & & \\
\hline 22 & Bahri & 10 & 6 & 10 & $60 \%$ & $100 \%$ & $\sqrt{ }$ & & \\
\hline 23 & Yekti Suhardani & 10 & 7 & 10 & $70 \%$ & $100 \%$ & $\sqrt{ }$ & & \\
\hline 24 & Farida Ellya & 10 & 6 & 7 & $60 \%$ & $70 \%$ & $\sqrt{ }$ & & \\
\hline 25 & Darman & 10 & 1 & 6 & $10 \%$ & $60 \%$ & $\sqrt{ }$ & & \\
\hline 26 & Ibrahim & 10 & 2 & 70 & $20 \%$ & $70 \%$ & $\sqrt{ }$ & & \\
\hline 27 & Hariyanto & 10 & 4 & 10 & $40 \%$ & $100 \%$ & $\sqrt{ }$ & & \\
\hline 28 & Adi Saputra & 10 & 1 & 8 & $10 \%$ & $80 \%$ & $\sqrt{ }$ & & \\
\hline 29 & Suprapto & 10 & 3 & 6 & $30 \%$ & $60 \%$ & $\sqrt{ }$ & & \\
\hline 30 & Sunarto & 10 & 1 & 7 & $10 \%$ & $70 \%$ & $\sqrt{ }$ & & \\
\hline 31 & Yaumidin & 10 & 3 & 80 & $30 \%$ & $80 \%$ & $\sqrt{ }$ & & \\
\hline 32 & Joko Suwondo & 10 & 8 & 8 & $80 \%$ & $80 \%$ & & & $\sqrt{ }$ \\
\hline 33 & Ismanto & 10 & 1 & 10 & $30 \%$ & $100 \%$ & $\sqrt{ }$ & & \\
\hline 34 & Budi Rohadi & 10 & 5 & 10 & $50 \%$ & $100 \%$ & $\sqrt{ }$ & & \\
\hline 35 & Mudai Yunus & 10 & 5 & 10 & $5 \%$ & $100 \%$ & $\sqrt{ }$ & & \\
\hline
\end{tabular}

Sumber: Data diolah, 2020 


\section{Kesimpulan}

Terjadi perubahan pengetahuan dan pemahaman hokum masyarakat di Desa Iringmulyo Kota Metro tentang Pendaftaran Tanah Menjamin Kepastian Hukum, yaitu dari tidak tahu menjadi tahu, dari tidak atau kurang paham tentang kepatian hukum dalam pendaftaran tanah menjadi paham, maka penyuluhan ini dikatakan berhasil.

\section{Ucapan Terima Kasih}

Terima kasih kepada LPPM Universitas Lampung yang sudah mendanai pengabdian masyarakat ini, mudah mudahan bermanfaat bagi masyarakat

\section{Daftar Pustaka}

Harsono Boedi. 2005. Hukum Agraria Indonesia : Sejarah Pembentukan Undang-Undang Pokok Agraria, Isi dan pelaksanaanya. Jakarta:Djambatan

Hermanses, R. 1981. Pendaftaran Tanah di Indonesia. Jakarta: Direktorat Jenderal Agraria
Parlindungan, A.P. 1994. Pendaftaran Tanah di Indonesia. Bandung: Mandar Maj

Subekti, R dan R. Tjitro SUdibyo. 1969. Kamus Hukum. Jakarta: Pradnya Paramita

Supriadi. 2008. Hukum Agraria,cetakan ke Dua jakarta. jakarta:Sinar Grafika

Supriadi. 2007. Hukum Agraria,Cetakan Pertama. Jakarta: Sinar Grafika

Yamin Lubis, Muhammad. 2001. JawabanJawaban atas Pertanyaan dalam Komentar atas Undang- Undang Pokok Agraria. Pusat Studi Hukum Agraria Fakultas Hukum USU: Medan

Undang-Undang No. 5 tahun 1960 tentang Peraturan Dasar Pokok-Pokok Agraria

Peraturan Pemerintah Nomor 24 Tahun 1997 tentang Pendaftaran Tanah

BPN Metro Gelar Penyuluhan PTSL 2020, https://www.rumpunmedia.com/bpnmetro-gelar-penyuluhan-ptsl-2020-inisyarat-dan-tahapannya.html, diakses pada tanggal 16 Februari 2020 